\title{
The seepage flow analysis of main dam stability in Way Sekampung dam development project
}

\author{
Tommy Andreant ${ }^{1}$, Lusmeilia Afriani ${ }^{2}$, Ofik Taufik Purwadi ${ }^{3}$, Andius D. Saputra ${ }^{4}$ \\ ${ }^{1-4}$ Civil Engineering Study Program, Lampung University, Bandar Lampung, 35145, Indonesia
}

\begin{abstract}
An analysis using a depression line method was conducted in two conditions, at normal water level $( \pm 124 \mathrm{~m})$ with a result of $1.11 \times 10-3 \mathrm{~m} 3 / \mathrm{s}$ and at flood water level $\pm 126.5 \mathrm{~m}$ with a result of $1.33 \times 10-3 \mathrm{~m} 3 / \mathrm{s}$. The capacity shows $(<1 \%)$ the average enters the reservoir, making it safe from the danger of distress. The safety calculations for pipping showed a bigger value than the filtration flow speed indication at the average value of 4,638 $(>4)$ which means that the dam will not make pipping symptoms.Based on the analysis conducted on the slope of the dam using slice method without entering the value of seismic coefficient obtained a safe number result in all loading conditions and the analysis by adding a seismic coefficient get a safe result except in two conditions, at elevation $\pm 126.5 \mathrm{~m}$ is SF 1.05 and at elevation \pm $124 \mathrm{~m} \mathrm{SF}$ is 1.05 .
\end{abstract}

\section{KEYWORDS}

Seepage, slope, stability

\section{INTRODUCTION}

Along with the development of the population, the human need for water is also increasing. Moreover, water is the main source of life for humans. One of the water sources is dams.

Dams have many benefits, including as a source of irrigation, family recreation, flood control, power plants, and waste storage. Dams shall be designed and maintained against safe seepage control. If not, the dam will run into problems due to excessive seepage. Excessive seepage may affect the safety of the dam itself if appropriate remedial action is not taken. The basic problem is to distinguish the extent to which the seepage affects a dam and what is the most appropriate remedial action, which must be taken to ensure that the seepage does not endanger the safety of the dam. One of the main factors for dam destruction is the immaturity of the geological and geotechnical aspects of planning that are directly related to the dam foundation. The dam should be built on a foundation that has rock quality with good bearing capacity. If the surrounding area has rock conditions with low bearing capacity, then geotechnical engineering can be carried out to overcome this problem. A foundation repair technique that is often used to overcome seepage and 
Tommy Andreant, Lusmeilia Afriani, Ofik Taufik Purwadi \& Andius D. Saputra

increase soil/rock bearing capacity in dams is grouting. Grouting is the process of injecting a cement

The solution into the soil that has been drilled beforehand and serves to glue the soil/rock so that its bearing capacity increases. The Way Sekampung dam was built to make the inflow from the Way Sekampung watershed downstream of the Batutegi dam and upstream of the dam plan to be optimally utilized for various purposes for the sake of improving people's lives rather than being wasted into the sea. The Way Sekampung dam in Lampung will have a height of 55 meters from the bottom of the excavation with a dam length of 362 meters. The top elevation of the dam is El. $+130 \mathrm{~m}$. This type of dam uses homogeneous soil fill, rock, and upright core. The topography of the regulating dam plan location is a hilly area on the left and a bit flat on the right. In general, the geological formations in this area are layered tuff rock with sand inserts. The climatology of this area is generally the rainy season from October to April of the following year, with an average rainfall of $1990 \mathrm{~mm}$. In this research, we will discuss the effect of seepage on the body and bottom of the dam on the stability of the Way Sekampung dam and how to overcome it with predetermined methods and theories,graphics, and reporting facilities.

\section{LITERATURE REVIEW}

A dam is a water structure specially built to block or hold the flow of water temporarily and the amount by using a homogeneous earth fill structure (Earthfill Dam), rock piles with a waterproof layer (Rockfill Dam), concrete construction (Concrete Dam), or various types other constructions (Soedibyo, 2003).The topography of the Way Sekampung dam shows the shape of the valley, with the slope of the left side relatively steeper than the right slope angle. The left slope angle is about 20 to 25 degrees with a hilly height between $92 \mathrm{~m}$ to $270 \mathrm{~m}$ above sea level.

Material for embankment dams is rock or soil material that is excavated from the area around the location of the prospective dam and the type of dam usually depends on the type, quality, and quantity of stockpile material available in the area. (Sosrodarsono, 1981). The waterproof material is a material that is necessary for the construction of an embankment dam and the type and stability of the dam are very dependent on the characteristics, quality, and quantity of the material that can be excavated for stockpiling in the watertight zone. (Sosrodarsono, 1981).

In planning a dam, it is necessary to pay attention to its stability against the dangers of landslides, slope erosion, and loss of water due to seepage through the dam body. Both the dam body and the foundation are required to be able to defend themselves against the forces caused by the presence of filtration water flowing through the gaps between the grains of soil-forming the dam body and the foundation. (Hardiyatmo, 2007). A slope is a land surface that opens and stands at a certain angle to the horizontal called a slope. Slopes in soil and rock are formed either by nature or man-made. Natural forces such as wind, water, ground movement, etc., can form natural slopes. Road construction, dams, are made by humans by forming slopes on the ground because slope construction is more economical than making retaining walls.

Considering that the slope is formed by the number of variables and the number of uncertainty factors, including soil parameters such as soil shear strength and pore pressure conditions, simplification is always carried out in analyzing various assumptions. In analyzing the stability of the slope of the Way Sekampung 
dam the author uses the Fellenius method. The calculation of slope stability using the Fellenius method can be used as follows (Das, 1994):

$$
F_{s}=\frac{\sum_{n=1}^{n=p}\left(c l+\left(N-U-N_{e}\right) \tan \alpha\right)}{\sum_{n=1}^{n=p}\left(T+T_{e}\right)}
$$

Information:

$$
\begin{array}{ll}
\mathrm{Fs} & =\text { safety factor } \\
\mathrm{C} & =\text { the number of cohesion per part }(\mathrm{kN}) \\
\mathrm{I} & =\mathrm{b} / \mathrm{cosb} \\
\mathrm{b} & =\text { width of each gutter }(\mathrm{m}) \\
\mathrm{a} & =\text { angle formed by the radius of the landslide plane }(\mathrm{o}) \\
\mathrm{N} & =\text { moment that holds the landslide field }(\mathrm{kN}) \\
\mathrm{U} & =\text { uplift force }(\mathrm{kN}) \\
\mathrm{Ne} & =\text { vertical component of the seismic load } \\
\mathrm{T} & =\text { moment causing shear } \\
\mathrm{Te} & =\text { tangential component of the seismic load }
\end{array}
$$

Earthquakes can cause both natural and man-made slope movements and collapse. Therefore, it needs to be considered in the calculation of the safety factor of slope stability. To calculate the effect of gravity due to earthquakes, what is often done in slope stability analysis is to use a numerical constant which is usually called the earthquake coefficient (k). This coefficient is given in percent of gravity. For example, a 10\% $(0.1 \mathrm{~g})$ gravity coefficient is often used in calculations.

$$
\begin{gathered}
k=\frac{A \times d}{g} \\
A \times d=z \times A c \times v
\end{gathered}
$$

Information :

$\mathrm{K}=$ earthquake coefficient

$\mathrm{Ad}=$ corrected earthquake acceleration $(\mathrm{cm} / \mathrm{s} 2)$

Ac $=$ basic earthquake acceleration $(\mathrm{cm} / \mathrm{s} 2)$

z $\quad$ = basic earthquake coefficient based on theearthquake zone map of Indonesia

$\mathrm{v} \quad=$ correction factor for the effect of local soil types

g = acceleration due to gravity

\section{METHODS}

The Way Sekampung Dam project is located between two villages, namely in Pekon Bumi Ratu, Pagelaran District on the right side of the river and Pekon Banjarejo, Banyumas District on the left side of the 
river, Pringsewu Regency, Lampung Province which is located at coordinates of 104048 '- 1050 08' East Longitude 5012 '- 5033 'South Latitude. To reach this location, it can be reached by using a four-wheeled or two-wheeled vehicle $\pm 3.0 \mathrm{~km}$ from the main access to the dam.

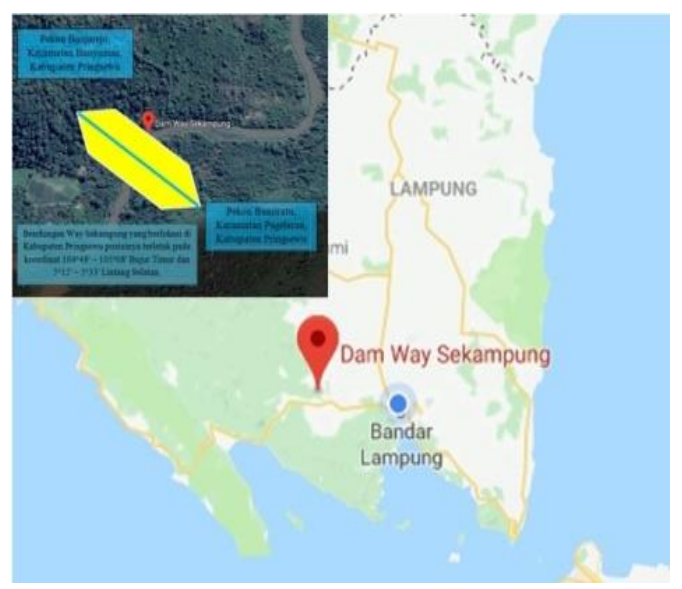

Figure 1. Research site

The data collection technique in this study is using secondary data. Secondary data used is in the form of soil test results at the research location in the independent laboratory owned by Waskita-Adhi Konsorsium as the contractor and some geological data is obtained from the Supervision Consultant of PT. Patria Use System for the Way Sekampung Dam Development Project, Pringsewu, Lampung. The data obtained includes:

1. Soil Investigation Index data and drill logs of the WaySekampug dam main dam.

2. Hydrological data

3. Data on the results of the embankment material test

\section{Dam geometry data}

The analysis ofthe flow of seepage was undertaken by drawing depression lines using manual methods and the help of Geostudio software. The analysis of theslope stability was carried out by comparing the results of the calculation of the Bishop and Ordinary (Fellenius) method with the loading of normal water level conditions, floodwater levels, and earthquake effects.

\section{RESULTS}

Analysis of the need for the amount of heap material

$$
\text { Volume }=\frac{\left(A_{1}+A_{2}\right)}{2} \times d
$$

Table 1. Recapitulation of material needs of Way Sekampung Dam

\begin{tabular}{|c|c|c|}
\hline No & Material Zone & Volume $\left(\mathrm{m}^{3}\right)$ \\
\hline 1 & Impermeable Core & 430144 \\
\hline 2 & Fine Filter & 140800 \\
\hline 3 & Coarse Filter & 123288 \\
\hline 4 & Stone Pile & 1498948,8096 \\
\hline 5 & Rip-Rap & 73413,12 \\
\hline & Total & 2266593,93 \\
\hline
\end{tabular}


From the calculations, the material needs of the Way Sekampung Dam stockpile as a whole amounted to about 2.2 million m3. Calculations made to calculate the needs of the amount of material is a simple calculation that is an estimate and not an exact amount, the needs in the field are adjusted to the amount of material available in each quarry - each material. From the results of the investigation survey with several sampling methods, the place under review can be said to be eligible as a quarry to guarantee the needs of heap materials if the amount available is estimated to be more than the material needs It is intended as a measure of anticipation if there is a change in volume and composition of the technical plan.

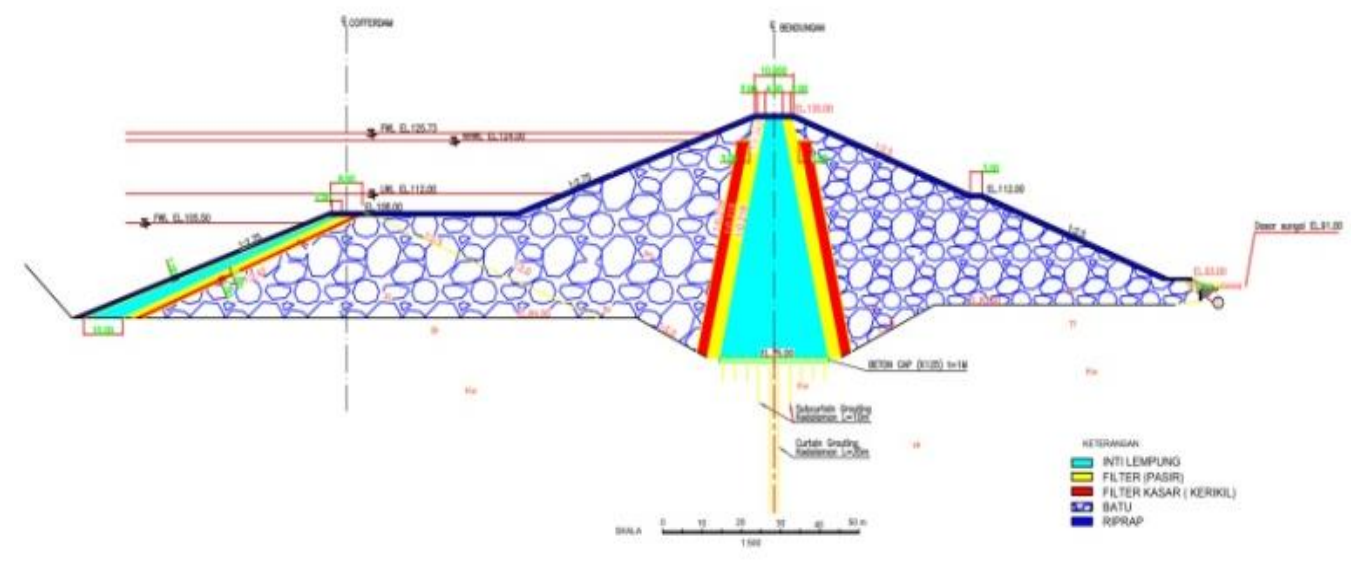

Figure 2. Division of dam material zones

Phreatic line or depression line as a saturation boundary line in the structure of the dam body. The phreatic level will separate the areas that have seepage from the areas that do not have seepage phenomenon.

$\begin{array}{ll}\text { Peak elevation } & =+130 \mathrm{~m} \\ \text { Normal Water Level } & =+124 \mathrm{~m} \\ \text { Flood water level } & =+126.5 \mathrm{~m} \\ \text { Elevation of the Top of the Weir Core } & =129.5 \mathrm{~m} \\ \text { Elevation of the Core of the Weir } & =75 \mathrm{~m} \\ \text { Core Base Width } & =28 \mathrm{~m} \\ \text { Calculation of normal water level }(+124 \mathrm{~m}) & \\ \text { Calculation of flood water level }(+126.5 \mathrm{~m})\end{array}$

Table 2. Depression line coordinates

\begin{tabular}{cccc}
\hline \multicolumn{2}{c}{ Elevation $\mathbf{+ 1 2 4} \mathbf{~ m}$} & \multicolumn{2}{c}{ Elevation $\mathbf{1 2 6 , 5 ~} \mathbf{~}$} \\
\hline $\mathrm{x}(\mathrm{m})$ & $\mathrm{y}(\mathrm{m})$ & $\mathrm{x}(\mathrm{m})$ & $\mathrm{y}(\mathrm{m})$ \\
\hline$-16,3693$ & 0 & $-17,5282$ & 0 \\
0 & 32,7386 & 0 & 35,0565 \\
4 & 36,5202 & 4 & 38,8511 \\
8 & 39,9454 & 8 & 42,3068 \\
12 & 43,0992 & 12 & 45,5007 \\
16 & 46,0375 & 16 & 48,4847 \\
20 & 48,7992 & 20 & 51,2954 \\
24 & 51,4127 & 24 & 53,9599 \\
28 & 53,8997 & 28 & 56,4989 \\
32 & 55,1011 & 30 & 57,7265 \\
\hline
\end{tabular}




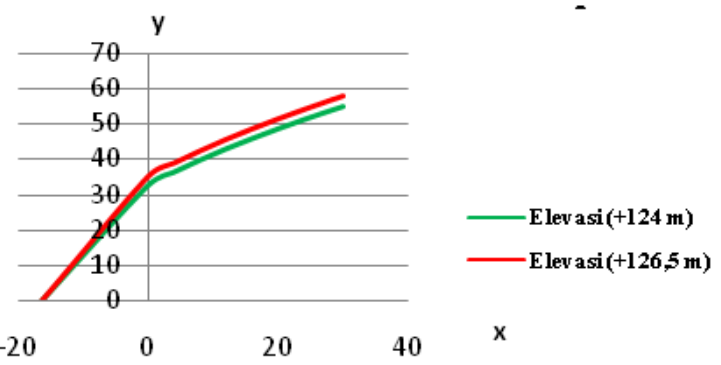

Figure 3. Depression line formation at the dam

Based on the calculation of the value of the graph above, Casagrande provides a formula for adjusting the depression line to a more suitable shape. Calculation of the adjustment of the points of intersection from the basic parabola to the actual flow line according to Casagrande at normal water level elevation $(+124 \mathrm{~m})$ is as follows:

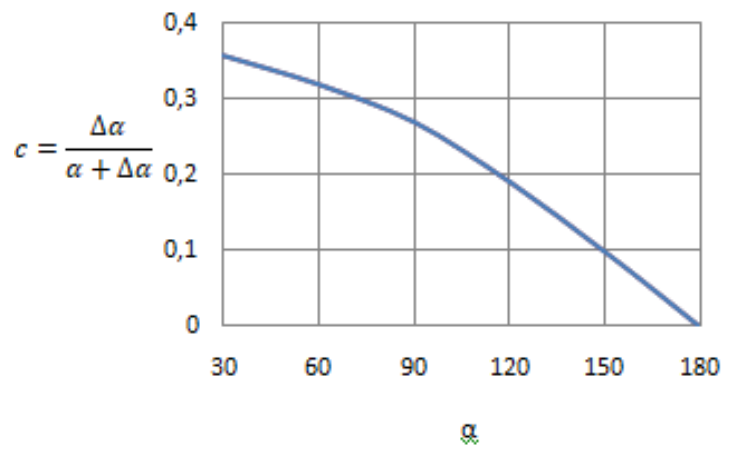

Figure 4. Value of $C$ casagrande

\section{Calculation of the elevation capacity of $\pm 124 \mathrm{~m}$ :}

The above calculation is repeated by entering the flood water level $\pm 124 \mathrm{~m}$, that is, with the water level from the bottom of the dam as high as $49 \mathrm{~m}$, then the seepage capacity value is obtained at $1.11 \times 10-3$ $\mathrm{m} 3 / \mathrm{s}$.

\section{Calculation of the elevation capacity of $\pm 126.5 \mathrm{~m}$ :}

The above calculation is repeated by entering the flood water level $+126.5 \mathrm{~m}$, namely with the water level from the bottom of the dam as high as $51.5 \mathrm{~m}$, then the seepage capacity value is $1.33 \times 10-3 \mathrm{~m} 3 / \mathrm{s}$.

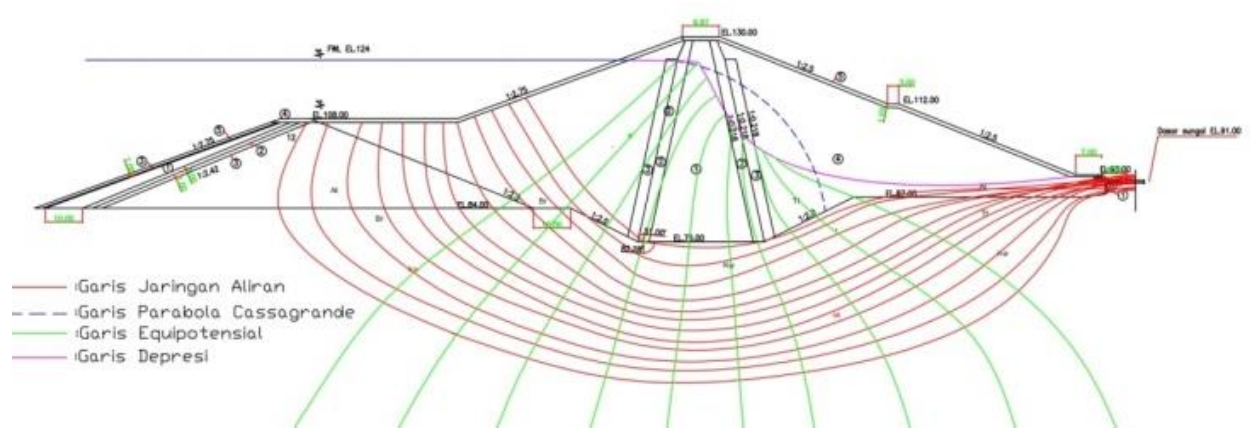

Figure 5. Lines work on the body and foundation of the dam at the water level of $+124 \mathrm{~m}$. 


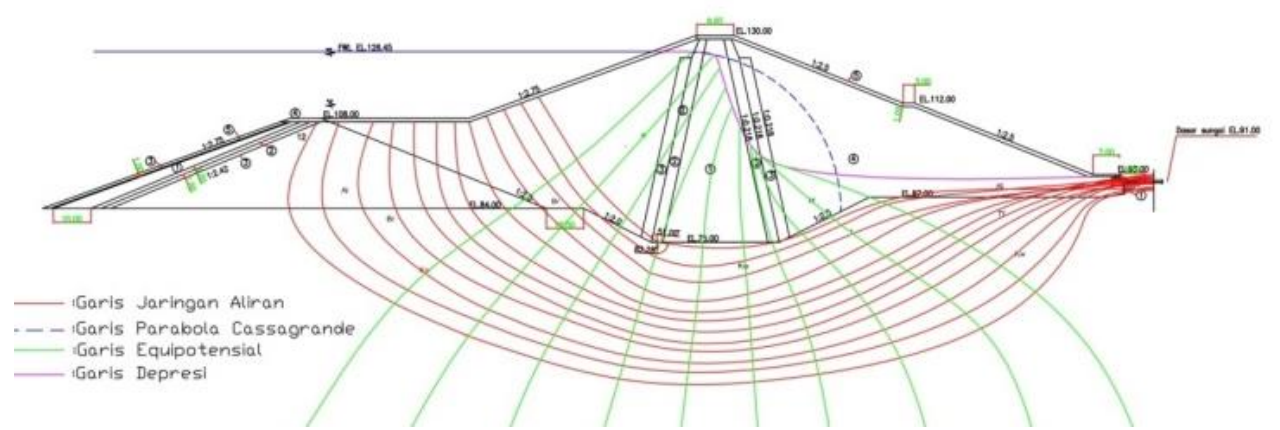

Figure 6. Lines work on the body and foundation of the dam at the water level of $+126,5 \mathrm{~m}$.

\section{Calculating the filtration flow rate}

The filtration flow capacity is the seepage capacity of water flowing downstream through the body and foundation of the dam.

Table 3. Specifications of the Way Sekampung Dam impermeable core material 4.4 Calculating the filtration flow rate.

\begin{tabular}{cccc}
\hline Void Ratio (e) & Porosity (n) & Specific Gravity (Gs) & permeability coefficient (k) \\
\hline 0,7078 & 0,41 & 2,6713 & $8,666 \times 10^{-8}$ \\
\hline
\end{tabular}

From the calculation of $\mathrm{Vc}=1.5863 \mathrm{~cm} / \mathrm{s}$ and $(\mathrm{Vs})=5.063 \times 10-4 \mathrm{~cm} / \mathrm{s}$. If critical velocity $(\mathrm{Vc})>$ seepage velocity $(\mathrm{Vs})$ then piping will not occur.

$$
\mathrm{SF}=4,638 \ldots \mathrm{OK}
$$

Table 4. Recapitulation of the calculation of seepage discharge with flownet and Seep/W method.

\begin{tabular}{|c|c|c|c|c|c|c|c|c|}
\hline \multirow{3}{*}{ Metode } & \multicolumn{8}{|c|}{ Seepage Value } \\
\hline & \multicolumn{3}{|c|}{ Grouting } & \multicolumn{3}{|c|}{ Without Grouting } & \multirow[b]{2}{*}{$\begin{array}{c}\text { Q/zin } \\
(1 \% \text { QInflow) }\end{array}$} & \multirow[b]{2}{*}{ information } \\
\hline & $\begin{array}{c}\text { M.A } \\
\pm 112 \mathrm{~m}\end{array}$ & $\begin{array}{c}\text { M.A } \\
\pm 124 \mathrm{~m}\end{array}$ & $\begin{array}{c}\text { M.A } \\
\pm 126,5 \mathrm{~m}\end{array}$ & $\begin{array}{c}\text { M.A } \\
\pm 112 \mathrm{~m}\end{array}$ & $\begin{array}{c}\text { M.A } \\
\pm 124 \mathrm{~m}\end{array}$ & $\begin{array}{c}\text { M.A } \\
\pm 126,5 \mathrm{~m}\end{array}$ & & \\
\hline \multirow{2}{*}{$\begin{array}{l}\text { SEEP/W } \\
\text { Depression } \\
\text { Line }\end{array}$} & $5,98 \times 10^{-5}$ & $9,95 \times 10^{-5}$ & $1,09^{-4}$ & $9,77 \times 10^{-5}$ & $1,57 \times 10^{-4}$ & $1,71 \times 10^{-4}$ & & secure \\
\hline & & & & $1,11 \times 10^{-3}$ & & $1,11 \times 10^{-3}$ & $9 \times 10^{-2} \mathrm{~m}-2 / \mathrm{dt}$ & secure \\
\hline
\end{tabular}

\section{Calculation of dam slope stability}

The stability of the dam slope is determined by several internal factors, including the soil design parameters used in the embankment material, here are the results of testing the soil material used in the main dam in Way Sekampung Dam.

Table 5. Soil design parameters of the Way Sekampung Dam

\begin{tabular}{|c|c|c|c|c|c|}
\hline Material & Zone & $\mathrm{\gamma}\left(\mathrm{kN} / \mathrm{m}^{3}\right)$ & $\mathrm{C}(\mathrm{kPa})$ & $\phi\left({ }^{\circ}\right)$ & $\mathrm{K}(\mathrm{m} / \mathrm{dt})$ \\
\hline Impermeable Core & 1 & 18,8385 & 37,9517 & 22 & $8,666.10^{-8}$ \\
\hline Fine Filter & 2 & 13,7292 & 35,2058 & 17,26 & $8,327.10^{-6}$ \\
\hline Coarse Filter & 3 & 13,8273 & 21,672 & 30,25 & $1,071.10^{-5}$ \\
\hline Rock & 4 & 19,61 & 3 & 41,1 & $5.10^{-1}$ \\
\hline Rip-Rap & 5 & 19,61 & 3 & 41,1 & $5.10^{-1}$ \\
\hline
\end{tabular}




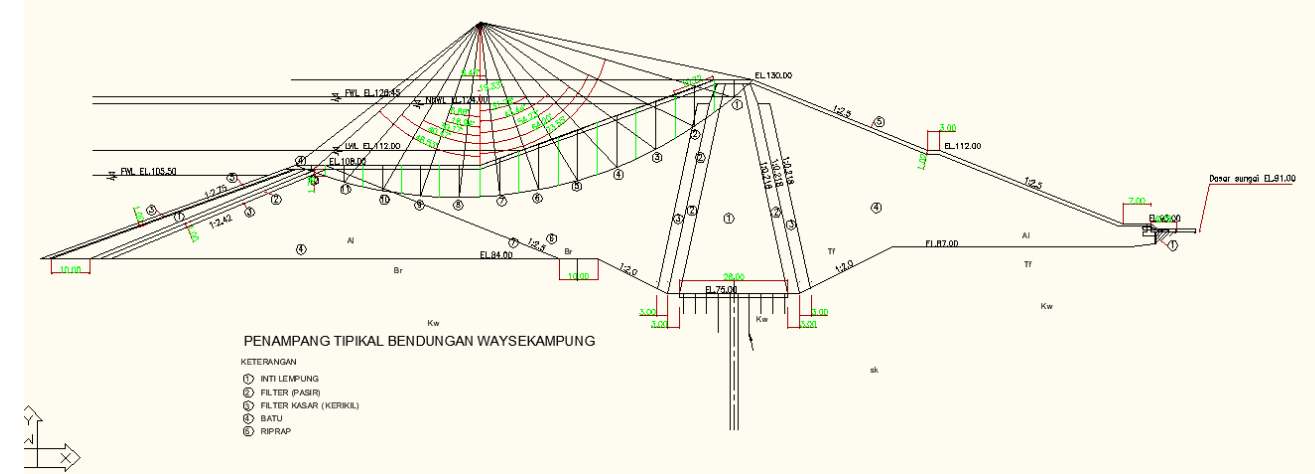

Figure 7. Slope analysis of the upstream embankment with slice method

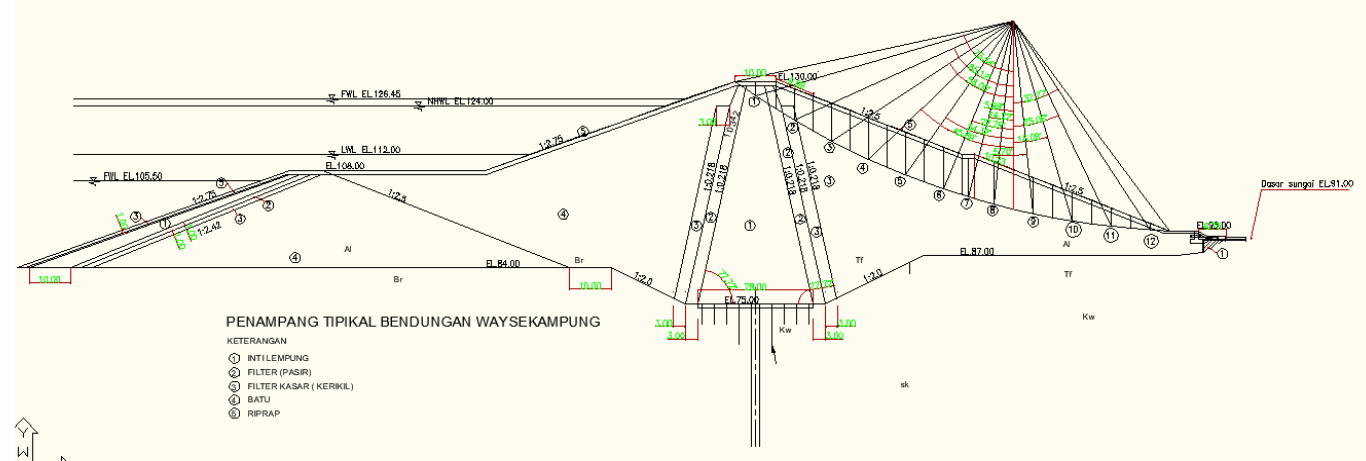

Figure 8. Slope analysis of the upstream embankment with slice method

\section{Determining the seismic coefficient}

The planned area for the Dam Regulating Dam Way Sekampung is included in the coefficient zone (Z) in the $E$ earthquake area, which is 1.20.

Table 6. Correction factors of rock types

\begin{tabular}{lcc}
\hline \multicolumn{1}{c}{ Basic Type Ts } & Predominant Period $(\mathbf{V})$ & Rock Correction Factor \\
\hline Rock & Ts $<0,25$ & 0,80 \\
Diluvium & $0,25<$ Ts $<0,50$ & 1,00 \\
Aluvium & $0,50<$ Ts $<0,75$ & 1,00 \\
Soft Alluvium & Ts $>0,75$ & 1,20 \\
\hline
\end{tabular}

Table 7. Calculation of the 10-500 year return period earthquake coefficient

\begin{tabular}{ccccc}
\hline $\begin{array}{c}\text { Repeat Period T } \\
\text { (Year) }\end{array}$ & $\begin{array}{c}\text { coefficient zone } \\
(\mathbf{Z})\end{array}$ & $\begin{array}{c}\text { base earthquake } \\
\text { acceleration (Ac) }\end{array}$ & $\begin{array}{c}\text { foundation type } \\
\text { parameters (v) }\end{array}$ & $\begin{array}{c}\text { earthquake } \\
\text { coefficient }\end{array}$ \\
\hline 10 & 1,20 & 0.127 & 0,90 & 0.137 \\
20 & 1,20 & 0.155 & 0,90 & 0.167 \\
50 & 1,20 & 0.196 & 0,90 & 0.212 \\
100 & 1,20 & 0.227 & 0,90 & 0.245 \\
200 & 1,20 & 0.255 & 0,90 & 0.275 \\
500 & 1,20 & 0.289 & 0,90 & 0.312 \\
\hline
\end{tabular}

The parameter of the type of foundation as a building support is rock, with a value of $v=0.90$ so that the design earthquake acceleration for the 100 year return period can be found with the formula: 


$$
A d=Z \times A c \times v
$$

$\mathrm{Ac}=0.227 \times 980$

$=222.46$

$\mathrm{Ad}=(1.20) \times 222.46 \times 0.90$

$=240.25 \mathrm{gal}$

Earthquake coefficients can be found with the formula:

$$
K=\frac{A d}{g}
$$

$\mathrm{K}=(240.25) / 980$

$=0.245$ gal.

Table 8. Recapitulation of slope stability calculation results without seismic load fellenius method

\begin{tabular}{ccccccccc}
\hline & \multicolumn{7}{c}{ SF Value Without Seismic Load } \\
\cline { 2 - 9 } Method & \multicolumn{7}{c}{ Upstream (Hulu) } & \multicolumn{4}{c}{ Downstream (Hilir) } \\
\cline { 2 - 9 } & Finished & MA & MA & MA & Finished & MA & MA & MA \\
& Construction & $\pm 112 \mathrm{~m}$ & $\pm 124 \mathrm{~m}$ & $\pm 126,5 \mathrm{~m}$ & Construction & $\pm 112 \mathrm{~m}$ & $\pm 124 \mathrm{~m}$ & $\pm 126,5 \mathrm{~m}$ \\
\hline \multirow{2}{*}{ Fellenius } & 2,08 & 1,74 & 1,78 & 1,8 & 2,88 & 2,89 & 2,89 & 2,87 \\
& (Secure) & (Secure) & (Secure) & (Secure) & (Secure) & (Secure) & (Secure) & (Secure) \\
\hline
\end{tabular}

\begin{tabular}{|c|c|c|c|c|c|c|c|c|}
\hline \multirow{3}{*}{ Method } & \multicolumn{8}{|c|}{ SF Value With Seismic Load } \\
\hline & \multicolumn{4}{|c|}{ Upstream (Hulu) } & \multicolumn{4}{|c|}{ Downstream (Hilir) } \\
\hline & $\begin{array}{c}\text { Finished } \\
\text { Construction }\end{array}$ & $M A \pm 112 m$ & $M A \pm 124 m$ & $\begin{array}{c}\text { MA } \\
\pm 126,5 \mathrm{~m}\end{array}$ & $\begin{array}{c}\text { Finished } \\
\text { Construction }\end{array}$ & $\begin{array}{c}\text { MA } \\
\pm 112 \mathrm{~m}\end{array}$ & $\begin{array}{c}\text { MA } \\
\pm 124 \mathrm{~m}\end{array}$ & $\begin{array}{c}\text { MA } \\
\pm 126,5 \mathrm{~m}\end{array}$ \\
\hline Fellenius & 1,97 (Secure) & $\begin{array}{c}1,15 \\
\text { (Unsecured) }\end{array}$ & $\begin{array}{c}1,15 \\
\text { (Unsecured) }\end{array}$ & $\begin{array}{c}1,05 \\
\text { (Unsecured) }\end{array}$ & 1,92 (Secure) & $\begin{array}{c}1,92 \\
\text { (Secure) }\end{array}$ & $\begin{array}{c}1,92 \\
\text { (Secure) }\end{array}$ & $\begin{array}{c}1,91 \\
\text { (Secure) }\end{array}$ \\
\hline
\end{tabular}

Table 9. Recapitulation of slope stability calculation results with seismic load felleniusmethod

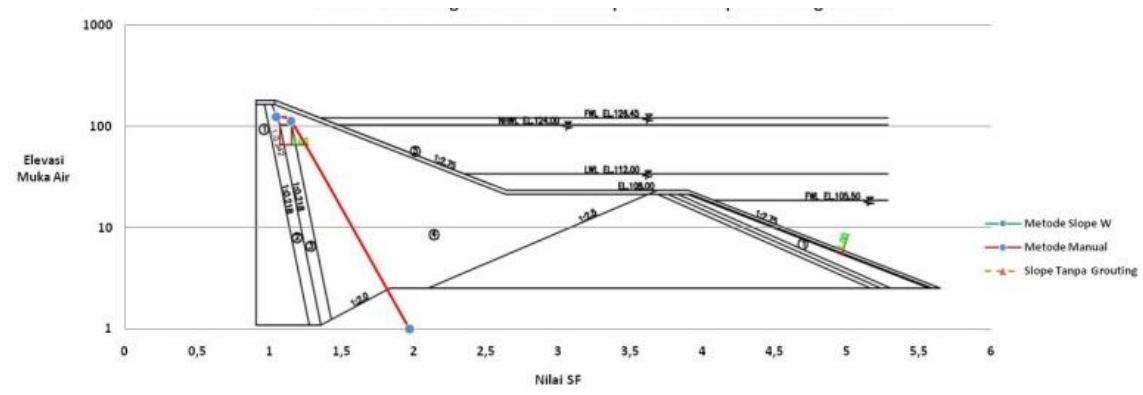

Figure 9. Graph of SF value without earthquake load in upstream

In the analysis by manual method (slice method), in Figure 9 it can be concluded that the Safety Factor value on the slope of Way Sekampung Dam also shows the value of fluctuations. In the chart, it can be seen that the load influence factor caused by the hydraulic force of dam disposal capacity does not mean that the SF value will decrease because the smallest SF value (critical) obtained in the analysis is at NWL water level $(+124 \mathrm{~m})$, which is 1.74 and the largest number of $\mathrm{SF}$ is at water level $(+0 \mathrm{~m})$ or when construction is 
completed, which is 2.08. At water level LWL $(+112 \mathrm{~m})$ the SF value is 1.78 and under FWL conditions $(+126.5$ $\mathrm{m})$ the SF value is 1.8 indicating that the slope is still safe from avalanche hazards.

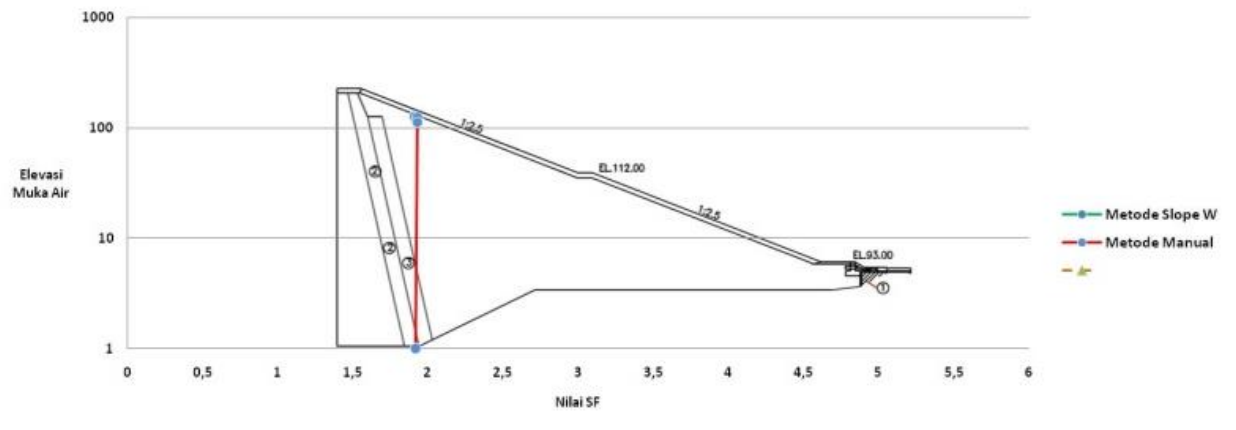

Figure 10. Graph of SF value without earthquake load in downstream

In the analysis by manual method (Slice method), in Figure 10 it can be concluded that the value of Safety Factor on the slope of Way Sekampung Dam shows a volatile value. In the figure, it can be seen that the influence of the amount of load caused by the hydraulic force of the dam discharge does not indicate that the SF value is getting smaller, because the largest SF value obtained in the analysis is at the LWL water level $(+112 \mathrm{~m})$, which is 2.89 and at NWL $(+124 \mathrm{~m})$ which is 2.89 and the smallest SF number is at the FWL water level $(+126.5 \mathrm{~m})$ which is 2.87 . At water level $(+0 \mathrm{~m})$ the $S F$ value is 2.88 , which indicates a safe condition from landslide symptoms and hazards.

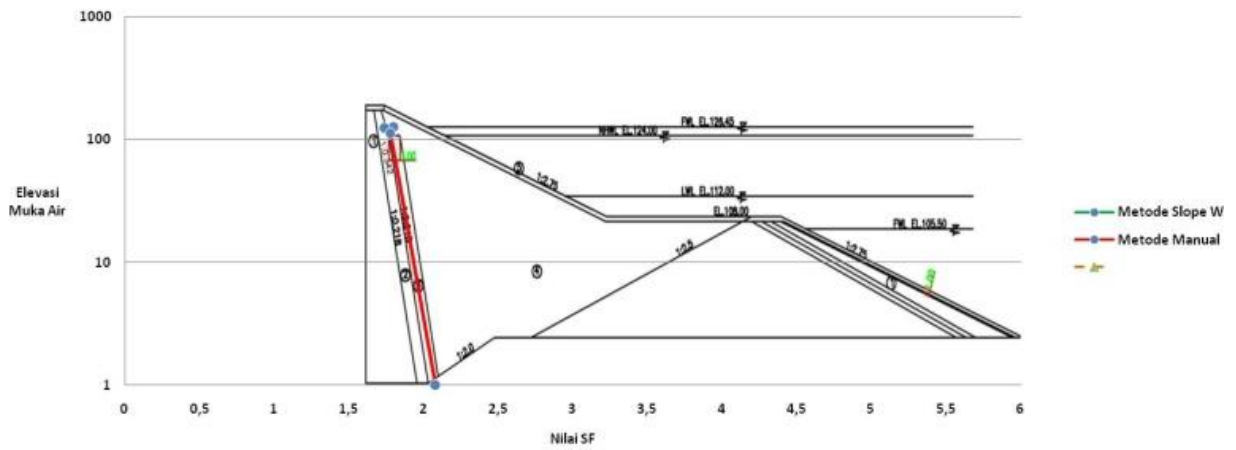

Figure 11. Graph of SF value against earthquake load in upstream

In the analysis by manual method (slice method), in Graph 6 it can be concluded that the value of Safety Factor on the slope of Way Sekampung Dam also showed a significant decrease in value. In the graph, it can be seen that the influence of the magnitude of the load caused by seismic load and hydraulic force resulting from the high discharge of the dam makes the dam tilt in unsafe conditions, namely at nwl water level $(+124 \mathrm{~m})$ with a value of SF 1.05. and FWL $(+126.5 \mathrm{~m})$ with a value of SF 1.05 which should be greater than the provisions of SNI: $8064: 2016$, which is 1.10 . At water level $(+0 \mathrm{~m})$ the SF value is 1.97 , which indicates safe conditions from landslide hazards. 


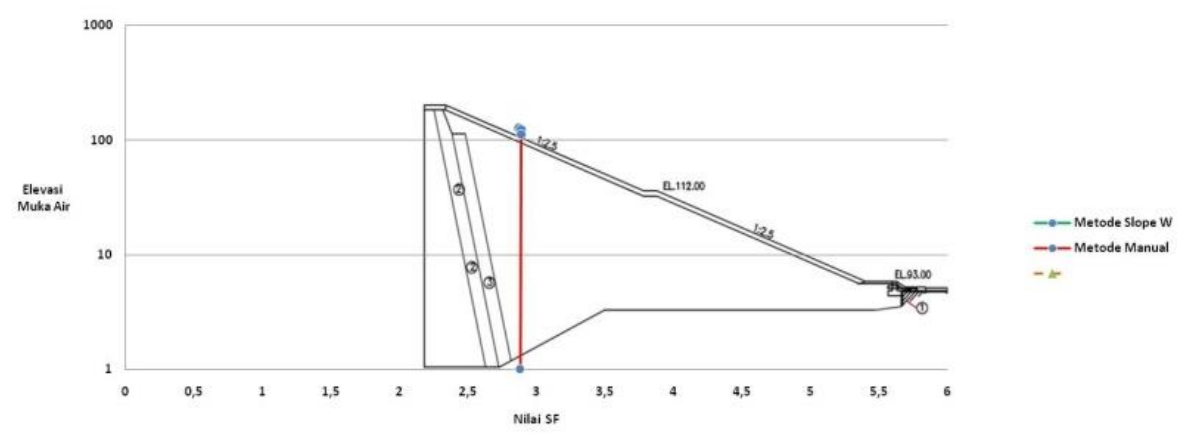

Figure 12. Graph of SF value against earthquake load in downstream

In the analysis by manual method (slice method), in Figure 12 it can be concluded that the value of Safety Factor on the slope of Way Sekampung Dam also shows a volatile value. In the chart, it can be seen that the influence factor of the magnitude of the load caused by seismic load and hydraulic load resulting from the high discharge of the dam does not indicate that the SF value will be reduced, because the smallest SF value obtained in the analysis was at the water level of FWL $(+126.5 \mathrm{~m})$ and the largest number of SF was at $\mathrm{nwl}$ water level $(+124 \mathrm{~m})$ which is 1.93 and $\operatorname{LWL}(+112 \mathrm{~m})$ which is 1.9 and at water level $(+0 \mathrm{~m}) 1.92$. Overall, the slopes are in a safe condition.

\section{CONCLUSION}

Safety calculations for pipping showed a greater value than the filtration flow speed indicating an average value of 4,638 ( $>4$ ) which means that the dam will not experience pipping symptoms. Debit analysis using SEEP/W method at low water level $( \pm 112 \mathrm{~m})$, normal water level $( \pm 124 \mathrm{~m})$, and flood water level $( \pm$ $126.5 \mathrm{~m})$ overall show safe figures showing $(<1 \%)$ the average discharge that goes into the dam. Analysis using depression line method was conducted in two conditions, namely at normal water level $( \pm 124 \mathrm{~m})$ with a result of $1.11 \times 10-3 \mathrm{~m} 3 / \mathrm{dk}$ and at flood water level $\pm 126.5 \mathrm{~m}$ with a result of $1.33 \times 10-3 \mathrm{~m} 3 / \mathrm{s}$. Capacity shows $(<1 \%)$ the average discharge enters the reservoir, making it safe against the danger of distress. Analysis conducted on the slope of the dam using the slice method without entering the value of the seismic coefficient obtained a safe number result in all loading conditions and the analysis by adding a seismic coefficient get a safe result except in two conditions namely at elevation 126.5 with SF 1.05 and at elevation 124 SF value 1.05 this can be caused by several things, decreased soil pore figures at the time the slope began to submerge. analysis can be done in more detail can be done by adding interviews with dam experts and supported by direct observations in the field specifically to facilitate research.

\section{REFERENCES}

Departemen Permukiman Dan Prasarana Wilayah. (2004). Analisis stabilitas bendungan tipe urugan akibat beban gempa. Jakarta: Kementerian Pekerjaan Umum dan Perumahan Rakyat.

Dewa, G.W. Rangga. (2014). Analisa stabilitas tubuh bendungan lolak Kabupaten Bolaang Mongondow Sulawesi Utara. Malang: Universitas Brawijaya. 
Tommy Andreant, Lusmeilia Afriani, Ofik Taufik Purwadi \& Andius D. Saputra

Dharmayasa, .I.G. (2018). Analisis rembesan di bawah tubuh bendungan urugan, Jurnal Paduraksa, 7. Denpasar, Bali.

Direktorat Jenderal Sumber Daya Air. (2003). Pedoman kriteria umum desain bendungan. Jakarta.

EM 1110-2-1901. (1986). Engineering and design seepage analysis and control for dams department of the army U.S. Army Corps of Engineers Washington DC.

Hardiyatmo, H.C. (2002). Mekanika tanah i (edisi 3), Yogyakarta: Gadjah Mada University Press.

Lontoh, R. Julistian. (2020). Analisa kestabilan bendungan lolak 1, Manado: Universitas Sam Ratulangi.

Lusmeilia, Afriani., Juansyah, Yan. (2016). Pengaruh fraksi pasir dalam campuran tanah lempung terhadap nilai cbr dan indeks plastisitas untuk meningkatkan daya dukung tanah dasar, Jurnal Rekayasa, 20(1).

Meshkabadi,Yousef. (2019). The effects of grout curtain parameters on uplift and piping phenomenon. Case Study: Sattarkhan Dam, Department of Civil Engineering, Tabriz Branch, Islamic Azad University, Iran.

Montarcih, Lily. (2010). Hidrologi Praktis. Bandung: Lubuk Agung.

Purwadi, Ofik Taufik., Cindy, Amelia Sukma. (2019). Perencanaan embung konservasi di taman rusa Universitas Lampung. $D D, 7(1)$. pp.162 - 172.

Putra, Andius D. (2013). Evaluasi dan kontrol pengaruh rembesan pada dam tailling Way Linggo, Kabupaten Tanggamus. Jurusan Teknik Sipil, Universitas Lampung, Bandar Lampung.

SNI-8062. (2015). Tata cara desain tubuh bendungan tipe urugan. Jakarta: Badan Standarisasi Nasional.

SNI-8064 (2016). Metode analisis stabilitas lereng statik bendungan tipe urugan.

SNI-8065. (2016). Metode analisis dan cara pengendalian rembesan air untuk bendungan tipe urugan. Jakarta: Badan Standarisasi Nasional.

SNI-8460. (2017). Persyaratan perancangan geoteknik. Jakarta: Badan Standarisasi Nasional.

Sosrodarsono, Suyono \& Takeda, Kensaku. (1977). Bendungan type urugan. Jakarta: Pradnya Paramita.

Sosrodarsono, Suyono \& Takeda, Kensaku. (1983). Hidrologi untuk pengairan. Jakarta: PT. Abadi.

Universitas Lampung. (2010). Format penulisan karya ilmiah Universitas Lampung. Bandar Lampung: Universitas Lampung. 